\title{
Large-volume lava flows fed by a deep magmatic reservoir at Ağrı Dağı (Ararat) volcano, Eastern Turkey
}

\section{Özgür Karaoğlu1,2,*, Abdelsalam Elshaafi², Mohamed K. Salah ${ }^{3}$, John Browning ${ }^{4}$,}

\author{
Agust Gudmundsson ${ }^{2}$ \\ ${ }^{1}$ Eskişehir Osmangazi University, Department of Geological Engineering, 26040 Eskişehir, \\ Turkey \\ ${ }^{2}$ Department of Earth Sciences, Royal Holloway University of London, Egham, TW20 0EX, \\ UK \\ ${ }^{3}$ Department of Geology, American University of Beirut, Riad El Solh 1107 2020, Beirut, \\ Lebanon \\ ${ }^{4}$ Department of Earth Sciences, University College London, Gower Street, London WC1E \\ 6BT, UK \\ *Correspondence to: Ö. Karaoğlu, ozgur.karaoglu@deu.edu.tr; cougarforever@ gmail.com
}

\section{Abstract}

Ağrı Dağı (Ararat), whilst being the tallest volcano in Turkey, is largely understudied. Two predominant peaks, Greater and Lesser Ağr1, make up the main edifice which has been built during four main phases. The most recent phase consisted of two volcanic eruptions. The respective surface area and volume of the first volcanic eruption were estimated at $96 \mathrm{~km}^{2}$ and $3.2 \mathrm{~km}^{3}$, whereas those of second eruption were much smaller with the surface area and volume estimated at $25 \mathrm{~km}^{2}$ and $0.6 \mathrm{~km}^{3}$. It is unusual for stratovolcanoes to produce basaltic eruptions of over $3 \mathrm{~km}^{3}$, although these and larger volumes are not uncommon in flood basalt-type eruptions. Large basaltic eruptions from stratovolcanoes normally require volcano-tectonic forcing (e.g. subsidence of collapse caldera and graben). However, there is no evidence for such volcano-tectonic forcing, during the most recent eruptions at Ağrı Dağı (Ararat), and therefore their comparatively large volume basaltic lavas need to be explained in a different way. Here we present an analytical method for calculating the source volume needed to supply magma to the eruptions at A $\breve{g r} 1$ Dağı. We find that the lava flow of $3.2 \mathrm{~km}^{3}$ was likely fed by a very large magma reservoir $\left(\sim 13,000 \mathrm{~km}^{3}\right)$ while the second flow of $0.6 \mathrm{~km}^{3}$ was fed by a 
reservoir of a much smaller effective size, or $\sim 2000 \mathrm{~km}^{3}$ ). 'Effective size' depends on what fraction of the reservoir participates in the eruption. We propose that entire reservoir supplied magma to the larger eruption, but only one of its compartments (about 1/5 of the total volume of the reservoir) supplied magma to the smaller eruption. Although seismic tomography indicates a magma reservoir at great depths $(>20-30 \mathrm{~km})$ below the Ağrı Dağı volcano, geochemical constraints on some of the later-formed rocks suggest an interaction between a shallow chamber (at 8-10 km depth) and the deep reservoir approximately $0.5 \mathrm{Ma}$. We provide numerical models whose results indicate that dykes injected from the lateral margins of the deep-seated reservoir are more likely to reach the surface directly rather than replenish the shallow magma chamber, suggesting also that the compartment for the second eruption was at the margin of the reservoir.

Keywords: large eruptions, magma chambers, magma reservoirs, volcano-tectonic forcing, crustal stresses, numerical models

\section{Introduction}

Magma or melt transport in the mantle is somewhat different from magma transport in the upper crust. Magma in the mantle, and partly in the lower crust, ascends by porous flow (Scott and Stevenson 1986). At shallower crustal levels, magma ascent is primarily through magmadriven fractures, that is, dykes. Dyke initiation and propagation is known to be partly controlled by regional stress fields, particularly those induced by crustal extension (e.g. Gudmundsson 1990, 2006; Daniels et al. 2012; Le Corvec et al. 2013; Maccaferri et al. 2014; Tibaldi 2015). Reservoirs which are underlying the shallow magma chamber may directly supply magma to areas outside of the stratovolcano (Gudmundsson 2006). Thus, less evolved magmas can erupt at the margins of stratovolcanoes while more evolved magmas erupt within the central parts of the stratovolcano.

Long-lived (>1 Ma) major volcanic edifices, such as a stratovolcano, a caldera volcano, or a large shield volcano (basaltic edifice), are commonly supplied with magma from a comparatively shallow crustal magma chamber (Browning et al. 2015; Gudmundsson 2016; Karaoğlu et al. 2016). While active, a shallow magma chamber acts as a sink for magma from a deeper magma source (or reservoir) (Gudmundsson 2012; Le Corvec et al. 2013). If new magma is injected from a deeper source during an eruption, that magma is likely to be of high density and may accumulate at the floor of the magma chamber (Coppola et al. 2009; 
Gudmundsson 2012). For an eruption to occur, the necessary conditions are that the magma chamber or reservoir (deep-seated magma chamber) ruptures and a fluid-driven fracture is able to propagate from the chamber to the surface (Gudmundsson 2012). There is a close relationship between the excess chamber pressure $\left(p_{e}\right)$ and magma recharge volume. At the most active volcanoes, rupture probability based on increasing excess pressure within the shallow chamber allow forecasts of dyke formation to be made in real time during magma recharge events (Browning et al. 2015). Stratovolcanoes in Turkey or elsewhere are commonly fed by shallow crustal magma chambers with estimated volumes that commonly range from about $5 \mathrm{~km}^{3}$ to $500 \mathrm{~km}^{3}$ (e.g. Chester 1993). Lavas issued from stratovolcanoes commonly range in volume between $0.01 \mathrm{~km}^{3}$ or less to $0.1 \mathrm{~km}^{3}$. Whilst these small eruption volumes can be considered 'normal', more voluminous eruptions are known to erupt at stratovolcanoes such as the 1981 lateral blast event at Mt Saint Helens, USA $\left(2.5 \mathrm{~km}^{3}\right)$, the Plinian eruption of Krakatoa, Indonesia in $1881\left(18-21 \mathrm{~km}^{3}\right)$, the 1991 dome collapse of Mt Unzen, Japan (1 km³), and the the Plinian eruption of Mt Nemrut, Eastern Turkey $\left(2.5 \mathrm{~km}^{3}\right)$ (Karaoğlu et al. 2005). Such events cannot be considered 'normal' as they are often associated with some degree of volcano-tectonic forcing, particularly graben or caldera formation or slip. By volcano-tectonic forcing we mean processes where the strain energy needed for displacement on a ring-fault of a caldera or the boundary faults of a graben is primarily of tectonic origin and the displacement cause reduction in volume, shrinkage, of the chamber/reservoir source. The volume reduction maintains the magmatic excess pressure in the source until the very end of the eruption, thereby squeezing out an exceptionally large fraction of the magma in the source and producing a large eruption (Gudmundsson, 2015, 2016). As said, we do not find evidence of volcano-tectonic forcing of this kind for these two eruptions and therefore seek alternative explanations for their sizes.

The type and composition of magma feeding an eruption can also influence the eruptive volume. For example, eruptions of felsic magmas commonly produce somewhat larger volumes than mafic ones, as exemplified by the eruption of Puyehue Cordon-Caulle which produced a rhyolitic lava flow of volume $0.5 \mathrm{~km}^{3}$ (Tuffen et al. 2013). Nevertheless, largevolume basaltic lava flows are commonly associated with flood basalt events such as the Deccan Plateau and the Columbia Basalt Plateau (Reidel et al. 2013).

It is seemingly rare for stratovolcanoes to produce both normal-size eruptions and large volume effusive eruptions without an element of local volcano-tectonic forcing (Gudmundsson, 2015, 2016). The Ağrı Dağı volcano, however, seems to exhibit such rare 
behaviour. Where most of the lavas that make up Ağrı Dağı were produced in relatively small eruptions $\left(<0.1 \mathrm{~km}^{3}\right)$, two massive basaltic lava flows with total volume exceeding $3.8 \mathrm{~km}^{3}$, that formed roughly during the period between the peak activity of the greater and lesser Ağr1 volcano. There is currently no explanation as to why such voluminous eruptions occurred during this time.

At the height of $5165 \mathrm{~m}$, Ağrı Dağı (Ararat) is the tallest volcano in Turkey and is comprised of two main peaks: Greater and Lesser Ağrı (Fig. 1). The most recent eruption (< $0.5 \mathrm{Ma}$ ) of A ğr Dağ1 occurred at 39 $30^{\prime} 20^{\prime \prime} \mathrm{N} / 44^{\circ} 22^{\prime} 23^{\prime \prime} \mathrm{E}$ and produced two generations of basaltic lava flows. The former volcanic eruption occupies an area of about $96 \mathrm{~km}^{2}$ and a volume of around $3.2 \mathrm{~km}^{3}$ while the later volcanic eruption was much smaller with an area of $25 \mathrm{~km}^{2}$ and a volume of $0.6 \mathrm{~km}^{3}$ (Fig. 1). The exact age difference between these lava flows, however, is unknown. The nearest major population centres (about 145,000 inhabitants) are only $6 \mathrm{~km}$ away from the volcano. Many of the stratovolcanoes in Eastern Turkey are poorly studied and understood, particularly in terms of their relationship to the current tectonics. This is an important issue because Ağrı Dağı and other neighbouring volcanoes are situated close to major strike-slip faults and areas of triple junction tectonics (Fig. 1).

The Ağrı Dağ1 volcano covers the largest area $\left(\sim 1100 \mathrm{~km}^{2}\right)$ of any volcano in Turkey. The volcano has erupted some $1150 \mathrm{~km}^{3}$ of volcanic materials over its $\sim 1.5 \mathrm{Ma}$ of activity (Y1lmaz et al. 1998) (Fig. 2). There are no calderas or grabens dissecting the volcano, which is in contrast with the common calderas on most stratovolcanoes in Eastern Turkey, such as the Nemrut caldera (Karaoğlu et al. 2005). The orientations of the parasitic cones and main volcanic fissures indicate that the dominant direction of tension in the area is NW-SE (e.g. Karakhanian et al. 2002). Dextral faults are common and form several pull-apart structures, some of which may be linked to volcanic activity (Karakhanian et al. 2002).

Ağrı Dağı is a typical stratovolcano mostly built up by calc-alkaline volcanic rocks (Y1lmaz et al. 1998, Fig. 2). Initial products (pre-cone phase) observed in the eastern part of the volcano are mainly intermediate (dacitic and andesitic in composition) pyroclastic rocks and lavas (e.g. Y1lmaz et al. 1998). K-Ar radiometric age data show that the oldest lavas are basaltic and were erupted between 1.51 Ma and 1.09 Ma ago (Sanver 1968; Pearce 1990). Basaltic lava flows overlay the oldest volcanic rocks. Following the first eruptive stages, the main cone of the volcano was built up mostly by andesite and dacite lavas. The last stage (flank eruption phase) is represented by alternating andesitic and basaltic lava flows from the main cone and parasitic 
scoria spatter cones on the flanks. During the last and most recent phase; basaltic lava flows were particularly dominant at the margin of the Ağrı Dağı volcano (Fig. 2).

One objective of this paper is to provide models that give insights into the magma storage systems feeding the Ağrı Dağı volcano and how their characteristics can account for the contrasting eruption volumes issued at the volcano. More specifically, we aim to find the feeding mechanism of the large-volume basaltic lava flows. Furthermore, in the absence of evidence of volcano-tectonic forcing contributing to the generation of the lava flows, we seek an alternative mechanism for their comparatively large sizes. In particular, we propose that the entire reservoir supplied magma during the eruption of the larger and more primitive lava flow. By contrast, we suggest that only a small compartment within the reservoir supplied magma during the eruption of the smaller and more evolved lava flow.

Geochemical constraints indicate that the Agri Dagi volcano was predominantly constructed from acidic to intermediate lavas and the later-formed rocks indicate an interaction between a shallow chamber (at 8-10 km depth) and the deep reservoir. As such, we have developed numerical models to study how of the magma systems of Ağr1 Dağ 1 volcano interact over time. These models are combined with approximate estimations as to the volume of the magma system underlying the Ağrı Dağı volcano in order to understand how and why such comparatively voluminous lavas can be erupted from stratovolcanoes such as Ağrı Dağı. The results provide information which is vital for understanding such large eruptions, particularly because they pose a significant threat to nearby population centres (e.g. Small and Naumann 2001).

\section{Tectonics, geology and geochemistry of the Ağrı Dağı volcano}

The East Anatolian High Plateau (EAHP) displays a very complex volcano-tectonic history of continental collision. After the closure of the Neotethyan Ocean as a result of AfricaEurasian convergence (Barka 1992; Okay and Tüysüz 1999; Bozkurt 2001), syn- and postcollisional magmatism dominate in the EAHP since the Middle Miocene (15 My, Lebedev et al. 2010). Four stages of Neogene-Quaternary volcanism have been identified: Middle Miocene (15.0-13.5 Ma), Late Miocene (10-9 Ma), Pliocene (5.8-3.7 Ma), and Quaternary (1.0-0.4 Ma) (Lebedev et al. 2010). Quaternary stratovolcanoes (e.g. Nemrut, Suphan, Ağrı Dağ1 volcanoes, Fig. 1) and shield volcanoes (e.g. Tendürek) on the Eurasian Plate produce predominantly calk-alkaline type eruptive materials (e.g. Pearce et al. 1990; Keskin et al. 1998; Y1lmaz et al. 1998; Keskin 2007, Lustrino et al. 2010), with minor alkaline igneous rocks (e.g. 
Innocenti et al. 1976, 1980; Pearce et al. 1990; Keskin et al. 1998; Y1lmaz et al. 1998; Alici et al. 2001; Keskin 2007). Lustrino et al. (2010) proposed that extensive volcanic activity on the Arabian plate, such as Karacadağ shield volcano, surfaced on a 35-40 km thick crust mostly during the Late Miocene to Quaternary, with the production of large amounts of alkaline basic rocks (Pearce et al. 1990; Ercan et al. 1991; Notsu et al. 1995). The formation of Ağr1 Dağ1 volcano has been tectonically linked to slab break-off and delamination in intraplate settings overlying hot asthenosphere through transtension (Y1lmaz et al. 1998; Shabanian et al. 2012; Sağlam-Selçuk et al. 2016).

Recent seismic tomography studies have documented that the crust in Eastern Turkey has an average of thickness $65 \mathrm{~km}$; it is thinner than average in the south, about $38 \mathrm{~km}$ (Arabian foreland (Angus et al. 2006; Ozacar et al. 2008; Cakir et al. 2000; Zor et al. 2003) (Fig. 1). Many studies suggest that the lithospheric mantle may be either completely absent (e.g. AlLazki et al. 2003) or very thin (e.g. Angus et al. 2006; Ozacar et al. 2008) beneath Eastern Turkey. Two controversial views have been expressed as to the origin of volcanism in Eastern Turkey; namely (i) that the region is reformed by melting and cooling of the asthenosphere and is as such an older lithospheric mantle (Keskin 2007), and (ii) that, on average, a $20 \mathrm{~km}$ thick lithosphere may have resulted from cooling of the asthenosphere from $15 \mathrm{Ma}$ to $7 \mathrm{Ma}$ (Angus et al. 2006). The crustal stress field has likely changed dramatically in the past 10 to $5 \mathrm{Ma}$ (Örgülü et al. 2003). These seismic- and petrology-based studies indicate that the uppermost mantle is partially molten and that the asthenosphere is close to the base of the crust, consistent with the existence of volcanism in the region (Örgülü et al. 2003).

The volcano-stratigraphy of the Ağrı Dağı volcano was mapped by Y1lmaz et al. (1998). Geological observations and published data (Türkünal 1980; Bingöl et al. 1989) show that 14 different types of geological units represent the stratigraphy of the region around the Ağrı Dağ1 volcano (Appendix 1). A cone-building phase produced mostly basaltic and rarely andesite rocks between 0.68 Ma and 0.5 Ma (Sanver 1968; Pearce 1990). The final stages of activity resulted in flank eruptions between 0.3 Ma and 0.04 Ma (Sanver 1968; Pearce 1990; Ercan et al. 1990; Notsu et al. 1995) and the most recent activity which occurred 20,000 years ago produced mostly andesitic lavas (Nagao et al. 1989). Since this period the volcano has been dormant, although there were unrest periods characterised by increased seismicity in 25002400 BC and 1840 AD (Karakhanian et al. 2002).

Here we consider the most recent basaltic lava flows erupted during the cone-building and flank eruption phases $(<0.5 \mathrm{Ma})$, which are located on the southern flank of the Greater Ağr1 
Dağı volcano (lava flows I and II, Fig. 3). The flows are easily distinguishable from the older basaltic lava flows (lava flow III, Fig. 3) by colour and lack of both erosion and alteration. These most recent basaltic lava flows were erupted from a NW-SE aligned series of scoria cones dated at $0.5 \mathrm{Ma}$ (Sanver 1968). The origin of those basaltic lava flows are - is poorly constrained in terms of petrology because previous sampling localities were not spatially defined (e.g. Pearce et al. 1990; Y1lmaz et al. 1998). Generally, though, the volcanic rocks of the Ağrı Dağı volcano are classified through a wide compositional range from trachy-basalt, tephrite/basanite, basaltic andesite, andesite, dacite and rhyolite (Fig. 4a) (e.g. Pearce et al. 1990; Nagao et al. 1989; Kheirkhah et al. 2009). A significant feature of the genesis and evolution of Quaternary magmas in Ağrı Dağı is the absence of basalt on the plot although the petrography shows them as basalt (Fig. 4). MORB-normalised trace element content of selected basaltic rocks are shown in Fig 4b. The basaltic lava flows at the main cone of the Ağrı Dağ 1 are more enriched in LREE than the marginal lavas (Fig. 4b).

\section{Injected material and reservoir volume}

In order to estimate the relative contribution of a shallow magma chamber and the contribution of a deeper magma reservoir to the eruptions of Ağrı Dağı we calculated first the total volume of injected materials, that is, magma volume leaving the chamber/reservoir during the eruption, from the lava flows I and II. In this study we used ArcGIS 10.1 to calculate the geometry and area of the Quaternary basaltic lava flows I and II (Fig. 3). The maximum thickness for each flow was estimated based on the elevation difference with the surrounding area using a SRTM (Shuttle Radar Topography Mission) compiled digital elevation model (DEM). The thickness of each individual lava flow increases from the margins to the centre, and so the greatest thickness was recorded at the centre of each flow that appears to be similar to lava shield (Fig. 2).

We can make an approximation to the shape and emplacement style of a lava shield. The volume of a lava shield is generally computed by approximating its shape as a truncated cone for flat topped volcanoes or a pyramid for a volcano with a distinct peak (Hasenaka 1994). Therefore, during this study the volume of each lava flow is calculated by approximating its shape to a cone, namely as:

$V_{e}=a(h / 3)$ 
where $V_{e}$ is volume of the volcanic unit; $a$ is area and $h$ is the maximum thickness of the unit. The area of the base of each individual volcanic unit was calculated using ArcGIS. The volume of eruptive surface materials is somewhat uncertain because part of the flow may be partially submerged by younger thick lava sequences (Andrew and Gudmundsson 2007). The total volume of injected material is a combination of the volume of an individual lava flow on the surface and the volume of the feeder dyke that fed the eruption. There are no available data in the study area on dyke geometries, such as length (strike dimension), thickness and depth (dip dimension), to calculate the volume of feeder dykes. As such, we use rough estimations of the average volume of dykes in Eastern Turkey, where the volumes do not exceed 0,004 $\mathrm{km}^{3}$ (Karaoğlu et al. 2016). Therefore, the error produced in the total injected material due to neglected volume of feeder dyke is very small.

The total injected material or magma Ve from Eq. (1) for lava flow I is around $3.2 \mathrm{~km}^{3}$ $\left( \pm 0,1 \mathrm{~km}^{3}\right)$ while the total injected material for lava flow II is around $0.6 \mathrm{~km}^{3}\left( \pm 0.02 \mathrm{~km}^{3}\right)$. Both volumes are quite similar to the sizes of monogenetic Holocene lava shields on the Reykjanes Peninsula, West Iceland, where the volume lava flow II is approximately the same size of the picrite lava-shields while the volume lava flow I is approximately the size of the olivinetholeiite shields (Andrew and Gudmundsson 2007). The primary picrite or olivine basaltic magmas in Iceland are believed to come from deep magma reservoirs rather than crustal shallow magma chambers (Meyer et al. 1985).

It is known that magma can accumulate at the crust-mantle boundary, which is commonly the situation for deep-seated reservoirs. A deep reservoir may directly feed surface eruptions or form a shallow magma chamber in the upper or middle crust. Such shallow chambers can form due to abrupt changes in the mechanical properties of the crustal rocks, particularly changes in stiffness (Young's modulus) of those rocks (Barnett and Gudmundsson 2014). In areas of intense magmatism such as Iceland, the crust-mantle boundary is commonly referred to as the magma layer (Hermance 1981; Bjornsson 1983; Gudmundsson 1987). The porosity or melt fraction differs through a magma reservoir due to buoyancy and reduced potential energy such that magma tends to move towards the top (shallowest depth) of the reservoir. Therefore, the greatest melt fraction is normally in the uppermost compartments of the reservoir and gradually decreases with depth (Richter and McKenzie 1984). The average melt fraction throughout a reservoir is commonly assumed at 0.25 (e.g. Richter and McKenzie 1984). The melt fraction of the lowest parts of a chamber may be higher if the reservoir is 


$$
V_{b}=\frac{V_{e}}{p_{e} \phi\left(\beta_{m}+\frac{\beta_{b}}{\phi}\right)}
$$
from the relation:

$$
K=\frac{E}{3(1-2 v)}
$$
would be:

continuously supplied with new primitive melt or magma from deeper sources in the mantle; for example, from the upper parts of a mantle plume (Gudmundsson 1987). The mechanical behaviour of a magma reservoir can be modelled to a first approximation as a poroelastic material (Gudmundsson 1986, 2016; Tibaldi 2015). Hence, the volume of a magma source during individual eruptions may be roughly estimated from Eq. 2, and is given by (Gudmundsson 1987, 2016; Browning and Gudmundsson 2015):

where $V_{e}$ is the volume of injected material in a single eruption, $\phi$ is fractional porosity of the reservoir, $p_{e}$ is the excess magmatic pressure in the reservoir, $\beta_{m}$ and $\beta_{b}$ are magma compressibility and bulk compressibility of the reservoir, respectively.

Magmatic excess pressure in the reservoir can be considered nearly equal to the in-situ tensile strength of the host rock at the time of rupture (Elshaafi and Gudmundsson 2016). The average in-situ tensile strength of the upper crust in Eastern Turkey is around 3.5 MPa (Gurocak et al. 2012). Compressibility is a measure of the relative volume change of a fluid or solid as a response to change in stress. The static compressibility of basaltic magma $\beta_{m}$ at $1100-1300{ }^{\circ} \mathrm{C}$ is around 1.25x $10^{-10} \mathrm{~Pa}^{-1}$ (Murase and McBirney 1973). The Young's modulus for the lowermost crust in Eastern Turkey is around $35 \mathrm{GPa}$ at a depth of $20 \mathrm{~km}$ (e.g. Gurocak et al. 2012: Karaoğlu et al. 2016). The bulk modulus $(K)$ for this part of the crust can be calculated

where $K$ is the bulk modulus, $\mathrm{E}$ is the Young's modulus and $v$ is the Poisson's ratio, whose average value for most solid rocks is around 0.25 (Gudmundsson 2011). Hence the compressibility of the crust in Eastern Turkey $\left(\frac{1}{K}\right)$ is around $4.28 \times 10^{-11} \mathrm{~Pa}^{-1}$.

From Eq. (2), if we assume the magma reservoir as partially melted with an average porosity of 0.25 throughout the reservoir as previously mentioned, the volume of the reservoir 
262

263

264

265

266

267

268

269

270

271

272

273

274

275

276

277

278

279

280

281

282

283

284

285

286

287

288

289

290

291

292

$V_{b}=3858 \times V_{e}$

This equation can be applied to estimate the volume of magma within a reservoir supplying magma to individual eruptions. From Eq. (4), the volume of the magma reservoir during the first eruption (lava flow I) is around $12,345 \mathrm{~km}^{3}$. By contrast, the volume of the magma reservoir during the second eruption (lava flow II) is, at $2,403 \mathrm{~km}^{3}$, that is less by a factor of about 5. A much larger reservoir is thus needed to give rise to the first lava flow than the second lava flow, as expected, assuming the reservoir's elastic properties remained the same for both eruptions. To explain this difference in reservoir size and related aspects during these eruptions, we created a suite of numerical models which investigate the distribution of stresses around a deep magma reservoir, with some constraints from seismic tomography.

\section{Seismic tomography models}

Low-velocity anomalies obtained from seismic tomography models can be used to detect magma chambers and reservoirs at depth. The seismic velocity model derived by Salah et al. (2011) is used to construct five vertical cross-sections of P-wave velocity across the area of Ağr1 Dağ1 volcano. This model is constructed through the application of the seismic tomography method of Zhao et al. $(1992,1994)$ on P-wave (primary wave) arrival times in Eastern Anatolia. This method has been applied successfully on arrival times collected from seismic events occurring in different tectonic circumstances. The method is adaptable to a general velocity structure which includes several seismic velocity discontinuities of complex topography. Initially, a 3-D grid net is set in the model space to express the 3-D velocity variations, the seismic velocities are taken as unknown parameters. Velocity at any point in the model is calculated by linear interpolation of the velocity values at eight grid nodes surrounding that point. The method uses an efficient 3-D ray-tracing scheme which accurately calculates travel times and ray-paths. More details about the method can be found in Zhao et al. (1992, 1994, 2012).

The Eastern Turkey data set comprises 31,730 P-wave arrival times generated by 7380 seismic events which were recorded by 39 seismic stations distributed relatively uniformly in the study area. Analysis of ray-path coverage (both in plan and vertical views) and the results of a checkerboard resolution test, and the hit count rates all imply that the obtained velocity anomalies are reliable features down to a depth of $45 \mathrm{~km}$ (Salah et al. 2011). P-wave velocity along the selected five cross-sections are shown in Figure 5. The model shows that prominent 
low P-wave velocity zones are visible at a depth range of 20-30 km beneath cross-sections 1-3 which strike in a NW-SE direction. Cross-sections 4 and 5 run in an NE-SW direction and exhibit low P-wave velocities that extend to the base of the upper crust (Fig. 5). These low Pwave velocity zones most likely indicate the occurrence of partial melt which can be interpreted as magma reservoirs beneath Eastern Anatolia (Hearn 1999; Calvert et al. 2000; Zor et al. 2003). These low-velocity zones seem to be consistent with previous seismological observations such as inefficient $S_{n}$ propagation and low $P_{n}$ velocity (Rodgers et al. 1997; AlLazki et al. 2004).

\section{Numerical models}

Whilst the seismic tomography data clearly indicates the presence of a deep reservoir there is little evidence in the tomography for a shallow magma chamber. However, geochemical constraints indicate that a shallow chamber was active approximately $5 \mathrm{Ma}$. As such, we built a suite of numerical models to test the stress conditions generated by different arrangements of magma chambers. The objective was to understand which conditions favour eruptions, and how could the relative size and location of those eruptions change due to the magma chamber arrangement.

The numerical models were built and solved using the finite element program COMSOL (www.comsol.com; cf. Zienkiewicz 1979; Deb 2006). The models are based on the real geological setting of the Ağrı Dağ volcano as interpreted from field measurements, seismic wave profiles, and InSAR data (Cavalié and Jónsson 2014) (Fig. 6). All models are two dimensional where the magma chambers and reservoirs are modelled as cavities or holes with prescribed loads given at their boundaries to simulate overpressure (Gudmundsson 2011; Gerbault 2012) (Fig. 6).

\subsection{Model set-up}

The geometry of our 2-D models is based upon a simplified E-W striking profile through the Ağrı Dağı volcano (Fig. 6). The magma sources in our models are elliptical, which is likely a simplification of real magma chamber geometries (e.g. Gudmundsson 2012; Le Corvec et al. 2015; Karaoglu et al. 2016). Although it has been shown previously that topography can play a role in distributing near surface stresses, the primary focus of our investigation is on the stress differences resulting from different boundary conditions applied to the magma chamber itself, where the host-rock properties as well as the depth, shape and 
size of the chamber are of main concern. Thus, we assume flat topography in all the models. The 14 different geological units as mechanical layers used in our models are based on direct geological observations and published literature (Y1lmaz et al. 1998) (Fig. 6). The values used to calculate depth of the magma chamber encompass all of these mechanical layers.

The depths of shallow magma chambers are commonly located within a few kilometres of the ground surface (cf. Gudmundsson 1998). In this study we assume the magma chamber depth to be $8 \mathrm{~km}$, although results are not sensitive to the shallow chamber depth. The depth of the deep seated magma reservoir is inferred from tomographic data at around $20 \mathrm{~km}$. In Fig. 6 we show only the model along an E-W strike. We performed two models, in order to investigate different eruption volumes i.e. (i) very large magma storage configuration for lava flow I (i.e. $\sim 13,000 \mathrm{~km}^{3}$ ), and (ii) a smaller lava flow II (i.e. $\sim 2,000 \mathrm{~km}^{3}$ ). We assumed two magma storage regions: 1) a deeper and larger reservoir at a depth of $20 \mathrm{~km}$ (with a diameter of $40 \mathrm{~km}$ and a thickness of $7 \mathrm{~km}$ ) a shallow magma chamber at $8 \mathrm{~km}$ depth (with a diameter of $16 \mathrm{~km}$ and a thickness of $5 \mathrm{~km}$ (Figs. 7a-b). The second model shows the same shallow magma chamber at $8 \mathrm{~km}$ depth (with a diameter of $16 \mathrm{~km}$ and a thickness of $2 \mathrm{~km}$ ) but with a much smaller volume deeper reservoir at $20 \mathrm{~km}$ depth (with a diameter of $30 \mathrm{~km}$ and thickness of $3 \mathrm{~km}$ (Figs. 7c-d).

In this model both magma chambers are residing within a heterogeneous, anisotropic elastic half space with Young's modulus (E) varying between individual layers from $50 \mathrm{GPa}$ to $20 \mathrm{GPa}$, as shown in Appendix 1. The shallower magma chamber is modelled considering two criteria. First, that most stratovolcanoes are fed by shallow chambers and, second, that geological data (some magma mingling textures in the rocks) and geochemical records indicate the existence of a shallow magma chamber beneath the volcano. The deeper magma reservoir is modelled based on our seismic tomography data. The shallower magma chamber assumed that has a maximum diameter of $16 \mathrm{~km}$ to a first approximation (Figs. 7a-b), whereas the deeper chamber or reservoir has a maximum diameter of $40 \mathrm{~km}$ for the first volcanic eruption to correspond the shrinkage of the volume of reservoir with the time. Poisson's ratio ( $v)$ does not vary significantly between individual layers; thus, in the models we use a constant typical value of 0.25 (Gudmundsson 2011). The E-W striking profile hosts predominantly horizontal layers where the layer thicknesses are taken from geological measurements (Fig. 2) and given in Appendix 1. All models are fixed at the corners, with boundary loads applied at the west and east edges and a free surface (a region free from shear stress) prescribed on the upper edge (Earth's surface). 
In addition to boundary loads prescribed at the edge of the models, to simulate tectonic stressing, we also load the internal cavities to simulate excess magma pressure, which is $5 \mathrm{MPa}$ in Figure 6. Magma-chamber rupture and dyke injection occur when the tensile stresses at any point at the boundary of the chamber/reservoir reach the tensile strength of the rock ( 0.5 to 9 MPa) (Amadei and Stephenson 1997). Laboratory tensile strengths of rocks reach up to about $30 \mathrm{MPa}$, but the in-situ tensile strengths are between 0.5 and $9 \mathrm{MPa}$, the most common values being 2-4 MPa (Gudmundsson 2011). By using excess pressure in the chamber/reservoir rather than total pressure, the effects of gravity are automatically considered (cf. Gudmundsson 2012). We use a triangular mesh with a maximum element size of $16 \mathrm{~m}$ and a minimum element size of $2 \mathrm{~m}$. Our simplified models show that the most likely area of chamber rupture and surface eruption is fed by interconnected magma reservoirs, shallow and deeper magma chambers (Fig. 7).

\subsection{Results}

To explore the potential magma propagation paths in the shallow crust beneath the Ağr1 Dağ1 volcano, we constructed a numerical model (Fig. 7). It is first necessary to consider the stress required for magma chamber rupture. In the simplest terms, a magma chamber roof will rupture and inject a dyke (or an inclined sheet) when (Gudmundsson 1990, 2011):

$p_{l}+p_{e}=\sigma_{3}+T_{o}$

where $p_{l}$ is the lithostatic pressure and $p_{e}$ is the excess pressure in the magma chamber, $\sigma_{3}$ is minimum principal compressive stress in the host rock, and $T_{0}$ is the tensile strength of the host rock, which ranges from 0.5 to $9 \mathrm{MPa}$ (Amadei and Stephenson 1997) and the average in situ tensile strength of the upper crust in East Turkey is around 3.5 MPa (in agreement with the common in-situ tensile strength range given above). When a chamber roof has failed in tension and a dyke is initiated then the magma follows the path or trajectories of maximum principal compressive stress, $\sigma_{1}$ (Gudmundsson 2011). Here we present first the results on crustal stresses induced solely by magmatic excess pressure within each chamber, ignoring initially the effects of any regional tectonic loading. In Fig. 7 we show the magnitudes of the minimum principal compressive (maximum tensile) stress, $\sigma_{3}$, and von Mises shear stress, $\tau$.

In an E-W profile, the maximum tensile and shear stresses concentrate at the lateral margins of each magma chamber and at the Earth's surface above the magma chamber. 
Complex stress patterns and interactions occur at depth due to the attitude and mechanical properties of the layers (Fig. 7a). There is a stress concentration zone or link between the deeper magma reservoir and the shallow chamber (Fig. 7b). Our model indicates that if magma propagates from the edge of the deeper reservoir it can reach the surface without interaction with the shallow chamber (Fig. 7a-b). However, this is partially dependant on the size and position of the deeper reservoir with respect to the shallow chamber. When the reservoir is smaller (Fig 7c) we find there is more likelihood of interaction with the shallow chamber. Here, the result show that the deeper magma reservoir has two options, so as to_either 1) feed the volcanic edifice from the lateral margins or 2) replenish the shallow magma chamber. Dykes that propagate from the central part will not feed an eruption but instead charge the shallow magma chamber. These models indicate that most lava flows at the central part of the volcano will produce more evolved lavas compared to those lavas fed from the reservoir margins.

\section{Discussion}

\subsection{Magma discharge mechanism}

Field studies and stratigraphy of the volcano indicate three major andesitic and two basaltic lava flow eruption cycles, with tens of intermediate-composition lava stacks, from cone building to late stage of the Ağrı Dağı volcano (Fig. 2; Y1lmaz et al. 1998). We focus on the latest basaltic lava flows ( 0.5 Ma; Sanver 1968) which record a single magmatic pulse and path from chamber to the surface. The combined volume of lava flows I and II represents only $0.06 \%$ of the volume of the estimated magma reservoir.

The variety of volcanic products along Ağrı Dağı volcano range from contemporaneous intermediate (dacitic and andesitic) to basic (basaltic) eruptions, indicating that the magma in this volcanic edifice may be derived from double magma chambers rather than a single magma source. The more evolved intermediate volcanic rocks (e.g. dacite and andesite) are generally concentrated at the central part of the edifice while the less evolved basaltic rocks are distributed at the margin. The injection of dykes from the central part of the deeper magma chamber (magma reservoir) could feed the shallow magma chamber while dyke injection from the margin of the deeper magma reservoir can propagate directly to the surface to feed eruptions. Field observations and the numerical model-models are consistent with this distribution, where less evolved magma can be observed around the periphery of the volcanic edifice whereas more evolved lava flows are present around the central part. 
The results of the numerical model, supported by geochemical data, indicate that dyke injection from the central part of a deep magma reservoir could feed a shallow magma chamber. The magma arriving at the shallower depths could then begin a fractionation or differentiation process prior to the chamber rupture condition $\left(p_{e}=T_{0} \approx 5 M P a\right)$ being reached. Thus, we suggest that the shallow magma chamber produces more evolved magma (e.g. the young andesitic rocks of age 0.1-0.02 Ma; Nagao et al. 1989); whereas the deep-seated magma reservoir produces the older and less evolved lavas (e.g. 0.3-0.049 Ma basaltic rock).

The magma reservoir volume underneath Ağrı Dağı appears to have reduced considerably over a period of $0.5 \mathrm{Ma}$. Our models indicate a volume reduction from $12,345 \mathrm{~km}^{3}$ for lava flow I to $2403 \mathrm{~km}^{3}$ for lava flow II. Magma storage shrinkage has been interpreted at other volcanic provinces such as in Iceland (Andrew and Gudmundsson 2007) and at the Al Haruj Volcanic Province, central Libya (Elshaafi and Gudmundsson 2016) (Fig. 8).

The first volcanic eruptions may be envisaged as injection from the margins of the deeper part of reservoir, whereas the second volcanic units may be injected from the uppermost part of the reservoir where more fractionated (lighter) basaltic rocks form. These basaltic magmas tend to occupy the uppermost part of a reservoir due to buoyancy. This process might explain why the volume of the reservoir changed substantially through time.

The sizes and areas of individual volcanic eruptions are mainly dependent on the sizes of the source magma chambers. There are many examples around the world showing that individual volcanic eruptions can occur on the order of several hundred square kilometres and have volumes exceeding several cubic kilometres. In fact, the largest basaltic lava flows reach estimated volumes of thousands of cubic kilometres (Fig. 8). Much more commonly, however, lava flows cover only small areas and have volumes less than $0.5 \mathrm{~km}^{3}$. As an example of a large historical lava flow, the 1783 Laki lava in Iceland covers $565 \mathrm{~km}^{2}$ and has a volume of about $15 \mathrm{~km}^{3}$ (Fig. 8). Also, some prehistorical (mainly 16-17 Ma old) individual lava flows of the Columbia River Plateau exceed volumes of $1000 \mathrm{~km}^{3}$. By contrast the lava flow erupted during the Krafla Fires in North Iceland, 1975-1984, covers an area of $0.3 \mathrm{~km}^{2}$ and its volume is about $0.17 \mathrm{~km}^{3}$ (Tryggvason 1984), while Etna lava flow for the 1991-1993 eruption has an area of $7.2 \mathrm{~km}^{2}$ and an estimated volume between 0.022 and $0.072 \mathrm{~km}^{3}$ (Harris et al. 2000) (Fig. 8). Many eruptions of 1-10 $\mathrm{km}^{3}$ and even larger can be explained by local volcano-tectonic forcing (e.g. Gudmundsson 2015, 2016) or continuous supply from a large deeper reservoir to the 
shallow chamber during the eruption (Gudmundsson 1987). By contrast 'normal' or small eruptions are usually less than $0.1 \mathrm{~km}^{3}$ and commonly fed by crustal shallow magma chambers with little or no continuous magma replenishment from a large deeper reservoir during the eruption (Gudmundsson 1987, 2016). Thus, in the absence of evidence for local volcanotectonic forcing, we assume that both lava flows I and II were emplaced from a deep reservoir in a normal eruption. This notion is supported by the chemistry of the lavas which indicates primitive magma, particularly of the larger lava flow.

To explain the difference in the volumes and chemistry of the lava flows, there are several possibilities. One possibility is that the size or volume of the entire reservoir decreased greatly between the two eruptions, in which case reduction in 'effective size' corresponds to reduction in true size. This possibility cannot be ruled out, but the reduction in size would then have to have happened within the time period of, at maximum, a few hundred thousand years (the lava flows are younger than 500,000 years). This is possible, but not very likely given that reservoir feeding volcanic systems, such as in Iceland, are commonly active for 0.5-1 Ma (Gudmundsson, 2006, 2012), and in many other areas similar reservoir are active for as long as millions of years. We therefore propose that the second and smaller eruption was supplied with magma from only a part of the reservoir, that is, for a compartment within the reservoir (see Gulen 1984 for discussion of the origin of the lavas). This suggestion is supported by the second and smaller lava flow being more evolved than the first and larger flow. It is clear particularly at the margin area of the Ağrı Dağı volcano (e.g. Kheirkhah et al. 2009). Thus, we suggest that only a fraction of the entire reservoir, a compartment (cf. Gudmundsson, 2012), contributed to the second eruption, thereby, partly at least, explaining their volume and chemical differences. Based on our calculations, the volume of that compartment is $2403 \mathrm{~km}^{3}$, or roughly $1 / 5$ that of the entire reservoir. Formation and maintenance of compartments in magma sources is discussed by Gudmundsson (2012). Furthermore, based on our numerical studies, this compartment was most likely at one of the margins of the reservoir.

\subsection{Tomography}

The tomographic data indicatesindicate the presence of an active deep magma reservoir having low P-wave velocities that extend to the base of the upper crust (Fig. 5). The magma reservoir may extend between $20-30 \mathrm{~km}$ in depth and 35-45 km in width, showing a NW-SEelongated tabular form (sill-like shape) in the crust (Figs. 5a-c). A diapiric-shaped dyke injection extending to the upper level of the crust in a NE-SW oriented profile (Fig. $5 \mathrm{~d}$ ) is 
clearly observed. In all profiles, we note that diapiric-shaped dyke injection feeding the main vent of the Ağrı Dağı volcano are not aligned below the main volcanic centers (Figs. 5a-d). It seems there is no magma source below the Lesser Ağr1 Dağı volcano. Greater Ağr1 Dağ1 volcano is not situated directly over the centre of the large deeper reservoir. This suggests that the reservoir may have migrated laterally following constructing of the Ağrı Dağı volcano during the past 1.5 Ma. The shallow magma chamber may be fossilised as a plutonic body directly below the Ağrı Dağı volcano, which would not be possible to detect it with tomographic imaging.

At least 4 historical volcanic eruptions are known to have occurred from Ağrı Dağ1 volcano (Karakhanian et al. 2002): (i) pyroclastic flow in 1840 AD from Greater Ağrı Dağı volcano, (ii) unclear eruption type in $1450 \mathrm{AD}$ from the SE slope of the Lesser Ağrı Dağ1 volcano, (iii) unclear eruption type in late $3^{\text {rd }}$-early $4^{\text {th }}$ century AD from Greater Ağrı Dağ 1 volcano, and (iv) explosive eruption-pyroclastic flow in 2500-2400 BC from the N-NE slope of Greater Ağrı Dağı volcano. Taking into account the huge magma reservoir below the volcano even a small future eruptive event coupled with volcano-flank instabilities could therefore pose a threat to the large populations living around Ağrı Dağı volcano, in Eastern Turkey and in the Armenian province.

\subsection{Numerical models in the geological context}

Our general numerical results provide insights into the mechanism of magma movement from a deep magma reservoir to the surface. Such a process can occur in two predominant ways: (i) the magma is fed directly to the surface from the lateral margins of the deep reservoir, or (ii) when the magma of deep origin is injected from the central part of the reservoir, the magma path (the dyke) connects with a shallow chamber which, in turn, ruptures and propagates a dyke to the surface. In the second case any erupting magma is then technically fed from the shallow chamber. Despite the tomography data which support an active deep magma reservoir (20-30 $\mathrm{km}$ in depth), the huge volume of intermediate and acidic lavas constructed at Ağrı Dağı stratovolcano (see Fig. 2) and other large stratovolcanoes most likely require the formation of a shallow magma chamber.

When taken together all of our results indicate that the bulk volume of the reservoir appears to be considerably reduced between the time of erupting Lava flow I and Lava flow II. The smaller size of the later magma reservoir increases the likelihood of interaction with the 
511

512

513

514

515

516

517

518

519

520

521

522

523

524

525

526

527

528

529

530

531

532

533

534

535

536

537

538

539

540

541

shallow chamber, assuming it has not already solidified which seems to be the case in Ararat volcano. Regardless of the size of each individual chamber, the conditions for rupture reamin the same, namely that the excess pressure must exceed the tensile strength of the wall rocks (Eq. 5). In both cases tested numerically (Fig. 7) we find that this failure is most likely at the margins of the chamber. Therefore more evolved basaltic magma remains-inside reservoir during the quiescent time among two eruptions may be moved upward eompartment-due to buoyancy effects of the reservoir to form compartment at the uppermost of the resevoir (Gudmundsson 2012), and then reservoir it would be ruptures after while-when Eq. 5 becomes satisfied again (Fig. 7c).

Basaltic rocks generated in lava flow II are generally more fractionated than lava flow I which is exactly as expected. The lack of data concerning the petrogenesis and geochemistry for both volcanic flows makes further analysis challenging. We therefore encourage a systematic field survey which would greatly improve the understanding of Ağrı Dağı volcano. We hope that this paper encourages further research into this volcano.

\section{Conclusions}

1) We calculated the total injected materials $V_{e}$ for two of the most recent basaltic eruptions at the Ağrı Dağı volcano. Lava flow I is around $3.2 \mathrm{~km}^{3}$ while the lava flow II is around $0.6 \mathrm{~km}^{3}$. In addition, we present an approach for estimating the volume of the reservoir supplying each individual volcanic eruption. The effective reservoir volumes obtained were $12,345 \mathrm{~km}^{3}$ and $2403 \mathrm{~km}^{3}$ for lava flows I and II, respectively.

$\underline{\underline{32}}$ ) Results of seismic tomography reveal a low-velocity zone at a depth of 20 to $30 \mathrm{~km}$ below the northwest part of the Ağrn Dağ1 volcano which interpret to be a deep magma reservoir. We do not find strong evidence of a shallow magma source from the present velocity models. This may indicate that the shallow magma chamber has already solidified.

z3) We explore two scenarios to explain the difference in volume of these two flows. One is that the absolute reservoir volume decreased between the two eruptions. This is possible, but not very likely since the likely time between the eruptions is not very large in comparison with the lifetimes of large reservoirs. The other scenario involves reservoir compartments. In this scenario, while the less evolved lavas around the volcano was feeding only by deep reservoir, a comparatively small compartment within the reservoir contributed magma to the eruption, 
542 which generated lava flows I and II at Ağrı Dağ1 volcano. In this view, calculated reservoir 543 volume of $2403 \mathrm{~km}^{3}$ for issuing lava flow II thus corresponds to that compartment and is about $544 \quad 1 / 5$ of the total volume of the reservoir.

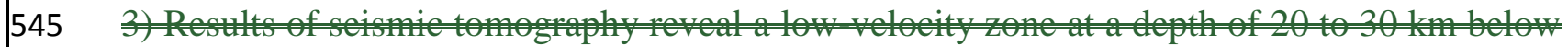
546 he northwest part of the Ağri Dag voleano which interpret to be a deep magma reservoir. We 547 donot find strengevidenee of ahallow magma solree frem the present veloeity models. This 548 may indicate that the shallow magma-hamber has already solidified.

549 4) The combined results from our tomography models and analytical calculations were used to 550 prepare a suite of numerical models. By simulating various crustal loading situations we show 551 the most likely stress state that promoted feeder-dyke propagation to erupt lava flows I and II. 552 Our data is useful in estimating the potential source of future eruptions at Ağrı Dağı volcano. 553 The interpretation of our numerical models suggests that A ğr1 Dağı basaltic volcanism has been 554 fed by either a shallow magma chamber located at about $8 \mathrm{~km}$ depth or lateral ends of a deep555 seated magma reservoir at 20-30 km depth which is supported by the geographical distribution 556 of these basaltic lava flows.-

557 5) The basaltic magma feeding Ağrı Dağı stratovolcano is enriched in LILE elements which 558 indicates an interaction between the shallow magma chamber and the deeper magma reservoir 559 just below the volcano. However, lesser evolved basaltic volcanic rocks at the margin of the 560 Ağrı Dağı volcano were presumably fed by a deeper magma reservoir with no interaction with 561 the shallow chamber.

\section{Acknowledgments} and Technological Research Council of Turkey (TUBITAK) International Postdoctoral Research Fellowship Programme. John Browning is supported by NERC project NE/N002938/1. We are greatful to the Editor Valerio Acocella and the reviewers, Alessandro Tibaldi and an anonymous reviewer, for comments which greatly improved this work. 
Al-Lazki A, Seber D, Sandvol E, Turkelli N, Mohamad R, Barazangi M (2003) Tomographic Pn velocity and anisotropy structure beneath the Anatolian plateau (eastern Turkey) and the surrounding regions. Geophysc Res Lett 30:24. doi:10.1029/2003GL017391.

Al-Lazki AI, Sandvol E, Seber D, Barazangi M, Turkelli N, Mohamad R (2004) Pn tomographic imaging of mantle lid velocity and anisotropy at the junction of the Arabian, Eurasian and African plates. Geophys J Int 158:1024-1040. doi:10.1111/j.1365-246X.2004.02355x.

Alici P, Temel A, Gourgaud A, Vidal P, Gundogdu MN (2001) Quaternary tholeiitic to alkaline volcanism in the Karasu Valley, Dead Sea rift zone, Southeast Turkey: Sr$\mathrm{Nd}-\mathrm{Pb}-\mathrm{O}$ isotopic and trace-element approaches to crust-mantle interaction. Int Geol Rev 43 (2):120-138.

Amadei B, Stephenson O (1997) Rock stress and its measurement. Chapman and Hall, London.

Ambraseys N.N, Melville C.P (1982) A History of Persian Earthquakes. Cambridge Univ. Press, New York, p. 219.

Andrew RE, Gudmundsson A (2007) Distribution, structure, and formation of Holocene lava shields in Iceland. J Volcanol Geoth Res 168(1):137-154.

Angus DA, Wilson DC, Sandvol E, Ni JF (2006) Lithospheric structure of the Arabian and Eurasian collision zone in Eastern Turkey from $\mathrm{S}$-wave receiver functions. Geophys J Int 166:1335-1346.

Barka AA (1992) The North Anatolian fault zone. Ann Tecton 6:164-195.

Barnett ZA, Gudmundsson A (2014) Numerical modelling of dykes deflected into sills to form a magma chamber. J Volcanol Geoth Res 281:1-11.

Bingöl E, Bal I, Can N (eds) (1989) Geological map of Turkey, scale 1:2000000, General Directorates of Mineral Research and Exploration, Ankara, Turkey.

Bjornsson H (1983) A natural calorimeter at Grimsvötn; an indicator of geothermal and volcanic activity. Jökull (33):13-18.

Bozkurt E (2001) Neotectonics of Turkey—a synthesis. Geodin Acta 14:3-30. 
Browning J, Drymoni K, Gudmundsson A (2015) Forecasting magma-chamber rupture at Santorini Volcano, Greece. Sci Rep 5:15785. http://doi.org/10.1038/srep15785.

Cakir O, Erduran M, Cinar H, Y1lmazturk A (2000) Forward modeling receiver functions for crustal structure beneath station TBZ (Trabzon, Turkey). Geophys J Int 140:341356.

Calvert A, Sandvol E, Seber D, Barazangi M, Roecker S, Mourabit T, Vidal F, Alguacil G, Jabour N (2000) Geodynamic evolution of the lithosphere and upper mantle beneath the Alboran region of the western Mediterranean: constraints from travel time tomography. J Geophys Res 105(B5):10871-10898.

Cavalié O, Jónsson S (2014) Block-like plate movements in eastern Anatolia observed by InSAR. Geophys Res Lett 41:26-31.

Daniels KA, Kavanagh JL, Menand T, Stephen JSR (2012) The shapes of dikes: Evidence for the influence of cooling and inelastic deformation. Geol Soc Am Bull 124(78):1102-1112.

Coppola D, Piscopo D, Staudacher T, Cigolini C (2009) Lava discharge rate and effusive pattern at Piton de la Fournaise from MODIS data. J Volcanol Geoth Res 184(1):174192.

Chester D (1993) Volcanoes and Society. Edward Arnold, London.

Deb D (2006) Finite Element Method, Concepts and Applications in Geomechanics. PHI Learning Private Limited, New Delhi.

Elshaafi A, Gudmundsson A (2016) Volcano-tectonics of the Al Haruh Volcanic Province, Central Libya. J Volcanol Geoth Res 325:189-202.

Ercan T, Fujitani T, Madsuda JI, Notsu K, Tokel S, Tadahide UI (1990) Dogu ve güneydogu Anadolu Neojen-Kuvaterner volkanitlerine iliskin yeni jeokimyasal, radyometrik ve izotopik verilerin yorumu: M.T.A Dergisi 110:143-164.

Gerbault M (2012) Pressure conditions for shear and tensile failure around a circular magma chamber; insight from elasto-plastic modelling. Geol Soc (Lond.) Spec Publ 367(1):111-130. 
Gudmundsson A (1986) Mechanical aspects of postglacial volcanism and tectonics of the Reykjanes Peninsula, Southwest Iceland. J Geophys Res-Solid 91(B12):1271112721.

Gudmundsson A (1987) Geometry, formation and development of tectonic fractures on the Reykjanes Peninsula, southwest Iceland. Tectonophysics 139(3-4):295-308.

Gudmundsson A (1990) Emplacement of dikes, sills and crustal magma chambers at divergent plate boundaries. Tectonophysics 176:257-275.

Gudmundsson A (2006) How local stresses control magma-chamber ruptures, dyke injections, and eruptions in composite volcanoes. Earth-Sci Rev 79:1-31.

Gudmundsson A (2011) Rock Fractures in Geological Processes. Cambridge University Press, Cambridge.

Gudmundsson A (2012) Magma chambers: formation, local stresses, excess pressures, and compartments. J Volcanol Geoth Res 237-238:19-41.

Gudmundsson A (2015) Collapse-driven large eruptions. J Volcanol Geoth Res 304:1-10.

Gudmundsson A (2016) The mechanics of large eruptions. Earth Sci Rev. http://dx.doi.org/10.1016/j.earscirev.2016.10.003.

Gurocak Z, Solanki P, Alemdag S, Zaman MM (2012) New considerations for empirical estimation of tensile strength of rocks. Eng Geol 145:1-8.

Gulen L (1984) Sr, Nd, Pb isotope and trace element geochemistry of calc-alkaline and alkaline volcanics, Eastern Turkey. Doctoral dissertation, Massachusetts Institute of Technology.

Hasenaka T (1994) Size, distribution, and magma output rate for shield volcanoes of the Michoac in-Guanajuato volcanic field, Central Mexico. J Volcanol Geoth Res 63:1331.

Hearn TM (1999) Uppermost mantle velocities and anisotropy beneath Europe. J Geophys Res 104:15123-15139.

Hermance JF (1981) Crustal genesis in Iceland: Geophysical constraints on crustal thickening with age. Geophysc Res Lett 8(3): 203-206. 
Innocenti F, Mazzuoli R, Pasquare G, Redicat di Brozolo F, Villari L (1976) Evolution of the volcanism in the area of interaction between the Arabian, Anatolian and Iranian plates (Lake Van, EasternTurkey). J Volcanol Geoth Res 1:103-112.

Innocenti F, Mazzuoli R, Pasquare G, Serri G, Villari L (1980) Geology of the volcanic area north of Lake Van (Turkey). Geol Rundsch 69: 292-322.

Irvine TN, Baragar WRA (1971) A guide to the chemical classification of the common volcanic rocks. Can J Earth Sci 8:523-548.

Karakhanian A, Djrbashian R, Trifonov V, Philip H, Arakelian S, Avagian A (2002) Holocene-historical volcanism and active faults as natural risk factors for Armenia and adjacent countries. J Volcanol Geoth Res 113:319-344.

Karaoğlu Ö, Özdemir Y, Tolluoğlu AÜ, Karabıyıkoğlu M, Köse O, Froger JL (2005) Stratigraphy of the volcanic products around Nemrut Caldera: implications for reconstruction of the Caldera Formation. Turk J Earth Sci 14:123-143.

Karaoğlu Ö, Browning J, Bazargan M, Gudmundsson A (2016) Numerical modelling of triple-junction tectonics at Karlıova, Eastern Turkey, with implications for regional magma transport. Earth Planet Sc Lett 452:152-170.

Kervyn M, Ernst GG, Klaudius J, Keller J, Kervyn F, Mattsson HB, Belton F, Mbede E, Jacobs P (2008) Voluminous lava flows at Oldoinyo Lengai in 2006: chronology of events and insights into the shallow magmatic system. B Volcanol 70(9):1069-1086.

Keskin M (2007) Eastern Anatolia: a hot spot in a collision zone without a mantle plume. In: Foulger GR, Jurdy D(eds). Plates, Plumes, and Planetary Processes. Geol Soc Am Spec Pap 430:693722.

Keskin M, Pearce JA, Mitchell JG (1998) Volcano-stratigraphy and geochemistry of collision-related volcanism on the Erzurum-Kars Plateau, North Eastern Turkey. J Volcanol Geoth Res 85:355-404.

Kheirkhah M, Allen MB, Emami M (2009) Quaternary syn-collision magmatism from the Iran/Turkey borderlands. J Volcanol Geoth Res 182(1):1-12.

Le Corvec N, Menand T, Lindsay J (2013) Interaction of ascending magma with preexisting crustal fractures in monogenetic basaltic volcanism: an experimental approach. $\mathbf{J}$ Geophys Res-Sol Ea 118(3):968-984. 
Le Corvec N, McGovern PJ, Grosfils EB, Galgana G (2015) Effects of crustal-scale mechanical layering on magma chamber failure and magma propagation within the Venusian lithosphere. J Geophys Res 120(7):1279-1297.

Lebedev VA, Sharkov EV, Keskin M, Oyan V (2010) Erratum: Geochronology of Late Cenozoic volcanism in the area of Lake Van, Turkey: an example of developmental dynamics for magmatic processes. Dokl Earth Sci 433(2):1031-1037.

Lustrino M, Keskin M, Mattioli M, Lebedev V, Chugaev A, Sharkov E, Kavak O (2010). Early activity of the largest Cenozoic shield volcano in the circum-Mediterranean area: Mt. Karacadag SE Turkey. Eur J Mineral 22:343-362.

Maccaferri F, Rivalta E, Keir D, Acocella V (2014) Off-rift volcanism in rift zones determined by crustal unloading. Nat Geosci 7(4):297-300.

Murase T, McBirney AR (1973) Properties of some common igneous rocks and their melts at high temperatures. Geol Soc Am Bull 84(11):3563-3592.

Meyer PS, Sigurdsson H, Schilling JG (1985) Petrological and geochemical variations along Iceland's neovolcanic zones. J Geophys Res-Solid 90(B12): 10043-10072.

Nagao K, Matsuda JI, Kita I, Ercan T (1989) Noble gas and carbon isotopic compositions in Quaternary volcanic area in Turkey. Bull Geomorphol 17:101-110.

Notsu K, Fujitani T, Ui T, Matsuda J, Ercan T (1995) Geochemical features of collisionrelated volcanic rocks in central and eastern Anatolia, Turkey. J Volcanol Geoth Res 64: 171-192. doi: 10.1016/0377-0273(94)00077-T.

Okay AI, Tüysüz O (1999) Tethyan sutures of northern Turkey. Geol Soc Spec Publ 156:475515.

Ozacar AA, Gilbert H, Zandt G (2008) Upper mantle discontinuity structure beneath East Anatolian Plateau (Turkey) from receiver functions. Earth Planet Sc Lett 269:426434.

Örgülü G, Aktar M, Türkelli N, Sandvol E, Barazangi M (2003) Contribution to the seismotectonics of Eastern Turkey from moderate and small size events. Geophysc Res Lett 30:(24).

Pearce JA, et al. (1990) Genesis of collision volcanism in Eastern Anatolia, Turkey. J Volcanol Geotherm Res 44:189-229. 
Reidel SP, Camp VE, Tolan TL, Martin BS (2013) The Columbia River flood basalt province: stratigraphy, areal extent, volume, and physical volcanology. Geol Soc Am Spec Pap 497:1-43.

Reilinger R, et al (2006) GPS constraints on continental deformation in the Africa-ArabiaEurasia continental collision zone and implications for the dynamics of plate interactions. J Geophys Res 111:B05411. doi:10.1029/2005JB004051.

Richter FM, McKenzie D (1984) Dynamical models for melt segregation from a deformable matrix. J Geol 92:729-740.

Riel B, Milillo P, Simons M, Lundgren P, Kanamori H, Samsonov S (2015) The collapse of Bárðarbunga caldera, Iceland. Geophys J Int 202(1): 446-453.

Rodgers AJ, Ni JF, Hearn TM (1997) Propagation characteristics of short-period Sn and Lg in the Middle East. B Seismol Soc Am 87:396-413.

Salah MK, Sahin S, Aydin U (2011) Seismic velocity and Poisson's ratio tomography of the crust beneath east Anatolia. J Asian Earth Sci 40:746-761. doi:10.1016/j.jseaes.2010.10.021.

Sanver M (1968) A palaeomagnetic study of Quaternary volcanic rocks from Turkey. Phys Earth Planet Inter 1:403-421.

Scott DR, Stevenson DJ (1986) Magma ascent by porous flow. J Geophys Res-Sol Ea 91(B9):9283-9296.

Selçuk AS, Erturaç MK, Nomade S (2016) Geology of the Çaldıran Fault, Eastern Turkey: Age, slip rate and implications on the characteristic slip behaviour. Tectonophysics 680:155-173.

Small C, Naumann T (2001) The global distribution of human population and recent volcanism. Global Environmental Change Part B. Environmental Hazards 3(3):93109.

Şengör AMC, Özeren MS, Keskin M, Sakınç M, Özbakır AD, Kayan I (2008) Eastern Turkish high plateau as a small Turkic-type orogen: implications for post-collisional crust-forming processes in Turkic-type orogens. Earth Sci Rev 90:1-48.

Shabanian E, Acocella V, Gioncada A, Habibolllah G, Belier O (2012) Structural control on volcanism in intraplate post collisional settings: Late Cenozoic to Quaternary examples of Iran and eastern Turkey. Tectonics 31:TC3013. 
Tezcan A (1995) Geothermal explorations and heat flow in Turkey. In: Gupta ML, Yamamo M (Eds.). Terrestrial Heat Flow and Geothermal Energy in Asia. Oxford and IBH Publishing Co. Pvt. Ltd., New Delhi, pp, 23-42.

Thordarson T, Self S (1993) The Laki (Skaftár Fires) and Grímsvötn eruptions in 17831785. B Volcanol 55(4):233-263.

Tibaldi A (2015) Structure of volcano plumbing systems: A review of multi-parametric effects. J Volcanol Geotherm Res 298:85-135.

Tryggvason E (1984) Widening of the Krafla fissure swarm during the 1975-1981 volcanotectonic episode. Bull Volcanol 47:47-69.

Tuffen H, James MR, Castro JM, Schipper CI (2013) Exceptional mobility of an advancing rhyolitic obsidian flow at Cordón Caulle volcano in Chile. Nature Communications 4.

Türkünal S (1980) Doğu ve Güneydoğu Anadolu'nun jeolojisi. TMMOB Jeoloji Mühendisleri Odası.

Vernant P, Nilforoushan F, Chéry J, Bayer R, Djamour Y, Masson F, Nankali H, Ritz JF, Sedighi M, Tavakoli F (2004) Deciphering oblique shortening of central Alborz in Iran using geodetic data. Earth Planet Sci Lett 223, 177-185. doi:10.1016/j.epsl.2004.04.017.

White JDL, Houghton B (2000) Surtseyan and related phreatomagmatic eruptions. Encyclopedia of volcanoes. Academic, San Diego, pp. 495-513.

Y1lmaz Y, Guner Y, Saroglu F (1998) Geology of the Quaternary volcanic centres of the East Anatolia. J Volcanol Geoth Res 85:173-210.

Zhao D, Hasegawa A, Horiuchi S (1992) Tomographic imaging of P- and S-wave velocity structure beneath northeastern Japan. J Geophys Res 97:19909-19928.

Zhao D, Hasegawa A, Kanamori H (1994) Deep structure of Japan subduction zone as derived from local, regional and teleseismic events. J Geophys Res 99:22313-22329.

Zhao D, Yanada T., Hasegawa A, Umino N, Wei W (2012) Imaging the subducting slabs and mantle upwelling under the Japan Islands. Geophys J Int 190:816-828.

Zienkiewicz OC (1979) The Finite Element Method. McGraw-Hill, New York, p. 787. 
774

777

778

779

780

781

782

783

784

785

786

787

788

789

790

791

792

793

794

795

796

797

798

799

800 structure of East Anatolian plateau from receiver functions. Geophysc Res Lett:30. doi:10.1029/2003GLO18192.

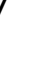

Zor E, Sandvol E, Gurbuz C, Turkelli N, Seber D, Barazangi M (2003) The crustal

(1)

9

80

(1)

2

3

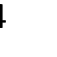

(1)

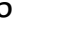


801

802

803

804

805

806

807

808

809

810

811

812

813

814

815

816

817

818

819

820

821

822

823

824

825

826

827

828

829

830

831

832

833

834

835

836

837

838

839

840

841

\section{Figure captions}

Figure 1. a) Map of the tectonic framework of Turkey; b) middle Miocene to recent volcanic centers in Eastern Turkey and location of population centres on a DEM-derived map. NAF: North Anatolian Fault, EAF: Eastern Anatolian Fault, KTJ: Karlova Triple Junction, VFZ: Varto Fault Zone.

Figure 2. a) Ağr1 Dağ1 volcano and surronding region; b) volcano-stratigraphy of the Ağrı Dağ1 volcano; c) geological map of the Ağrı Dağı volcano; d) geological map of the last two basaltic lava eruptions, flows I and II.

Figure 3. The last basaltic/most basaltic lava flows around Ağrı Dağı volcano. a-b) Google Earth Images of basaltic lava flows at around the Great and Lesser Ağr1 Dağı volcanoes; c-d) Images of the most recent lava flows (I-II).

Figure 4. a) $\mathrm{K}_{2} \mathrm{O}+\mathrm{Na}_{2} \mathrm{O}-\mathrm{SiO}_{2}$ (TAS) (Le Maitre 2002) diagram for the rock samples around Ağrı Dağı volcano (data taken from Gulen 1984; Pearce et al. 1990); alkaline-subalkaline line is according to Irvine and Baragar (1971); b) MORB-normalized multi-element diagrams for the volcanic rocks of the basaltic/most basaltic rock samples around Ağnı Dağ1 volcano (data taken from Gulen 1984; Pearce et al. 1990; Kheirkhah et al. 2009). Normalizing values are from Sun and McDonough (1989).

Figure 5. (a-e) Five vertical cross-sections of P-wave velocity beneath the area of the Ağrı Dağ volcano (see Fig. 1 for the location of the cross-sections). Low velocities are shown in red, whereas high velocities are shown in blue. Large stars and small circles show, respectively, the location of moderate/large earthquakes $(M \geq 5.0)$ and the microseismic activity in a $30 \mathrm{~km}$ wide-zone around the profile. The perturbation scale $( \pm 5 \%)$ is shown to the right. (f) The locations for these seismic profiles on the map.

Figure 6. 2-D numerical model setups. The 2-D example shown represents the geology of an E-W striking profile through Ağrı Dağ1 volcano. All 2-D models are layered $\mathrm{E}_{(1-14)}$ with each unit assigned a different value of Young's modulus. Magma chambers, represented as cavities, are given an excess pressure of 5 to $15 \mathrm{MPa}$.

Figure 7. Modelled stresses induced by excess magmatic pressure $\left(p_{e}\right)$ inside a shallow chamber of diameter $16 \mathrm{~km}$ and a deep reservoir of diameter $40 \mathrm{~km}$. a) Magnitudes of the minimum principal compressive (maximum tensile) stress $\left(\sigma_{3}\right)$. b) Magnitude of von Mises shear stresses $(\tau)$ The excess magmatic pressure in each chamber is $5 \mathrm{MPa}$ and is the only loading. Parts c) and d) show the same arrangement of shallow chamber and deep reservoir but in this case the reservoir is reduced in size with a diameter of $16 \mathrm{~km}$, and $30 \mathrm{~km}$ in respectively.

Figure 8. a) Area vs. volume constraints of some single lava discharge ratios for composite volcanoes and volcanic regions; b) Volume compilation for some historical eruptions. (1) This study; (2) Kervyn et al. (2008); (3) Haris et al. (2000); (4) Tryggvason (1984); (5) Thordarson 
842 and Self (1993); (6) Reidel et al. (2013); (7) White and Houghton (2000). Arrows highlighting 843 the last two basaltic eruptions of A $\breve{g r}$ Dağı volcano. 